\title{
Resistance and Acceptance on the Diffusion of Global Norms of Child Participation in Indonesia
}

\author{
Fuat Albayumi ${ }^{1}$, M. Fahri Priambudi ${ }^{2}$, Abubakar Eby Hara ${ }^{3}$ \\ \{uat@unej.ac.id ${ }^{1}, \underline{\text { mfahripriambudi@gmail.com }}{ }^{2}$, eby-hara.fisip@unej.ac.id $\left.{ }^{3}\right\}$ \\ Department of International Relations, FISIP University of Jember, Indonesia ${ }^{1,2,3}$
}

\begin{abstract}
The definition of what is important and who needs to be protected in the world community always changes. In 1990, through the adoption of the United Nations Convention on the Rights of the Child (CRC), the world community is determined to protect and make children a comprehensive person, complete with a series of rights as human beings. The consequence of CRC is that children are deemed necessary to engage in decision-making processes whose outcomes will affect the growth of their selfdevelopment. The United Nations Children's Fund (UNICEF) as a UN agency dealing with child welfare issues and international non-governmental organizations (INGOs) working on the issue of children rights are important norm entrepreneurs in spreading this norm. This study aims to analyze the diffusion of norms of child participation in Indonesia by using the conceptual framework of Martha Finnemore and Kathryn Sikkink on norms diffusion and of Amitav Acharya's concept on localization of norms. Using qualitative methods, this study found that within the Indonesian government, the diffusion of child participation norms has reached the final stage of norm diffusion, called internalization. In contrast, within Indonesian society the diffusion of the norms raises two types of resistance namely cultural and religious resistance
\end{abstract}

Keywords: Child rights; UN Conventions; global norms; Indonesia

\section{Introduction}

The world community always changes. The change made differences in the understanding of what is right and wrong, and who needs to be protected. For example, there has been changes in the concept of sustainable development in children's rights. In 1924, the international community began to recognize the need to ensure the safety of children, with the issuing of the Geneva Declaration on the Rights of the Child by the League of Nations [1].

After the Second World War, the United Nations established the United Nations Children 's Fund (UNICEF) to protect children affected by war. UNICEF extended its scope beyond the rights of European children when the UN Declaration on the Rights of the Child issued in 1959 [2]. The Declaration extends the right of the child in special protection to "develop physically, spiritually, morally, spiritually and socially in a healthy and normal way by respecting the liberty and dignity of the child" [1].

Child safety rights in conflict situations was raised in the First Additional Protocol to the Geneva Convention of 1977, which prohibited children under fifteen years old to get involved in conflict situations, and in particular, in the recruitment for armed groups. A more comprehensive regulation emerged from the adoption of the United Nations Convention on the Rights of the Child (hereafter CRC) in 1989 [1]. In addition, the Organization of Islamic 
Cooperation (OIC) Summit 2010 in Libya produced Tripoli Declaration on Development of Children's Forum for OIC Member States [3]. A series of Declarations mentioned above creates a strong message that child rights and protection become a subject to many initiatives, from research and publications to global conferences and projects.

The CRC, is the first international legal instrument to recognize the formal right of children. It means that the child is a subject in the process of shaping the identity and in an environment in which he or she grows and develops. Therefore, it is important to arrange conditions for the voice of the child to be heard, facilitated, and accommodated by adults. Recognition of children's participatory rights is catalyst for increasing the contribution of children to their communities.

The CRC mandates participating countries to reconstruct the role and position of children in the structure of society and in its relationship with adults. This mandate enables countries to listen to what the child says seriously. Recognizing a right of the child does not mean aborting an adult's responsibility to the child. Instead, children should not be left alone in fighting for their rights. The implementation of CRC in the recognition of children rights needs a commitment of adults to share their authority, to cooperate in articulating the life of the child, and to make the child a partner rather than an object in development [3].

Indonesia as one of the many countries that ratified the CRC, is obliged to adopt the values and spirit contained in the convention into its national legislation system. The penetration of the idea of child participation was initiated by UNICEF as the main entrepreneur norm in Indonesia. Continuously and systematically, UNICEF since the 1990s has assisted Indonesian government and non-state actors in child-related programs [4].

Based on the 2010-2035 Population Projection, in that period Indonesia has a demographic bonus; a condition where the population dependency ratio is below 50 percent. This condition indicates a decrease in the number of child-aged populations and they become significant productive-age population. This opportunity should be maximized by improving the quality of children as the next generation of the nation. The fulfillment of the right of participation will produce critical, sensitive and potential children so that they can grow to become adults and active citizens contributing to the development of the nation.

Nevertheless, promoting the idea of children's participation is often taken unserious by some Indonesians. It is seen as rhetorical or symbolic. Some people still consider children as persons who must have absolute obedience to adult and this cannot be compromised. People's perspectives generally regard children as objects, not subjects. This perspective is still dominant and is accompanied by the spread of terrors and threats in treating children [5]. As a result, the children become depressed and not free to express their opinion. This kind of attitude is in a direct contradiction with the underlying principles of child participation programs.

In some situation, many stakeholders in Indonesia (including the government, legislative members, law makers and society in general) have not made the issue of child protection as a priority. Initially the state's stance on this issue was often reactive and only attempts to 'extinguish the fire of problems', so that the state attitudes tend to 'satisfy' international demands and only provide non-systematic, and preventive ad-hoc solutions.

For sometimes, the state and other stakeholders considered the problem of children as not crucial, just something 'seasonal' and they only paid attention when there are certain cases. The issue of children was not a 'sexy' political commodity in a national legislation program, perhaps because legislators think children are not voters, unlike adults. The notion that the child protection agenda is a 'waste of money' because 'the indicators of success are difficult to measure' was often used as the reason for such neglectful behaviour. 
However, the attitude of the government later changed. It not only accommodated but also implemented the norms. How this happened will be the focus of this paper. The dynamics of resistance and acceptance to the norms of children's rights as illustrated above will be explored using a constructivist approach, particularly its concepts of the diffusion of norms. The norms diffusion relates to two mains issues namely the extent to which the idea of child participation evolved into norms, and then how the norms entrepreneurs advocate the diffusion of the norms in Indonesia.

\section{Method}

This study uses qualitative descriptive approach. The qualitative approach aims to understand the phenomenon holistically and thoroughly. This writing focuses on the diffusion of norms of child participation programs in Indonesia. This qualitative descriptive approach interprets and presents data related to the process of penetration and debate that indicate the occurrence of the diffusion of norms in Indonesia.

In this study, data obtained by literature study and refer mainly to the information in secondary sources and other relevant sources. Authors made also general observations by following news regarding children rights which enriched this writing. Data analysis used qualitative-deductive techniques which seeks to provide an in-depth understanding of a phenomenon.

This study uses a constructivist paradigm using the framework of Martha Finnemore and Kathryn Sikkink concerning the diffusion of norms. The concept of diffusion of norms emerging at the end of the Cold War is used to analyze how and why certain international norms were adopted by the countries in the world. Finnemore argues that the international norms promoted by international organizations can convincingly influence national policy by encouraging countries to adopt this norm in their national policies. The concept developed by Finnemore emphasizes the importance of the international environment in shaping the country's identity [6].

The international norm begins with the central idea possessed by numbers of individuals, organizations, or countries. The norms spreading worldwide normally go through the process called 'life-cycle norms', with three stages: (1) norm emergence, (2) norm acceptance, and (3) norm institutionalization [7].

In addition, this study will also use Amitav Acharya's framework of localization of international norms which include the acceptance, rejection and modification of the norms by local agents. Acharya's concept is important to explain the gap in the CRC implementation of children rights norms in the government and the society level.

Acharya said that the acknowledgment of the norms and norms entrepreneurs by local institutions and structures is important in the process of accepting or rejecting the norms [8]. The importance of local institutions and structures is evident in the discussion of advocating children's rights in developing countries. Following the increasing role of non-state actors in the penetration of norms, many organizations have emerged to assist and oversee the entry of the norms into the local bureaucratic system.

Localization will only occur when local practices and understanding are in line with interpretation of the norms by norm entrepreneurs and when society adopts legal products that then are implemented in accordance with international standards. Norm displacement occurs if the norm is not adopted into the system and the internalization process fails to gain significant 
influence on the local actors. Resistance occurs if the norm gets full rhetorical support (at least from the government) [8] but cannot work because the local actors are deliberately impeding [9].

By using the above theories, the next section will discuss the diffusion of child participation norms in Indonesia, its acceptance at the government level, and its resistance among Indonesian society.

\section{Result and Discussions}

This study proves three important things. The first is the appropriateness of Finnemore and Sikkink's diffusion theory of norms in understanding the acceptance of the norms of child participation in government level in Indonesia. International organizations (UNICEF) and non-governmental international organizations as norms entrepreneurs use norms of protection and child participation as platforms to teach what should be the interests of government and Indonesian society. The platforms resulted in the compliance of the Indonesian government over the ratification of the CRC. This is an entry point for the acceptance of the norms of child participation in Indonesia.

Second, it can be seen that at the level of government, Indonesia has reached the stage of norm internalization of child participation. A number of resistances still takes place, but such resistance does not interfere with overall acceptance of the norms. To understand fully, this study also included an Acharya concept of localization of norms to explain the accommodation and resistance to the diffusion of child participation norms.

Third, it is known that there is resistance in the Indonesian society toward the diffusion of norms of child participation. The resistance has two types of resistance: cultural resistance and religion-based resistance.

\section{A. Conformity with the Diffused Norms}

The 1945 Indonesian Constitution in article 28B of paragraph 2 states that, "Every child has the right to survival, to grow and to develop and to be entitled to protection from violence and discrimination". The State has endorsed legal products that ensure the implementation of child participation, such as Law no. 22/2002 and Law no. 17/2016 on Child Protection as the first law concerning to the entire operationalization of this program. The government initiates Child Friendly Nation program called IDOLA (Indonesia Layak Anak), which has a vision of a nation that can protect and support the rights of children [3]. In order to achieve this, the Ministry of Women Empowerment and Child Protection launched the Child Friendly City (KLA - Kota Layak Anak) program in 2015[4].

Furthermore, in the area of child participation, the government takes further action. Since the enactment of Law No. 22 of 2002 on Child Protection, the government experimented with initiating the formation of a forum for the participation of Indonesian children. This forum has been through a number of restructuring and evaluation, and then become the National Children's Forum (FAN-Forum Anak Nasional) since 2015. The FAN is funded by the Indonesian Ministry of Woman Empowerment and Child Protection and has branches called Regional Children's Forum (FAD-Forum Anak Daerah) in each province. The Children's Forum was established gradually, from national to village level, even in some cases up to the level of the neighborhood (Rumah Tangga/RT) level [3]. 
However, the top-down legislation and initiatives that have been implemented does not mean that the diffusion of child participation norms has been well internalized in the public and private spheres [1]. In Indonesia, there is a gap between the state and society in the process of diffusion of norms of child participation. The next section will discuss this gap.

B. Internalization of Norm at the Government Level

The first stage in the diffusion of norms is the emergence norm. This stage is marked by UNICEF's efforts through Innocenti of Research Center (IRC) as a center for research of children issues around the world. Through scientific publications on the rights of the child, UNICEF is able to disseminate information about those rights. There are some International Non-Governmental Organizations (INGOs) that interpret and dramatize this issue. The involvement of INGOs in the interpretation of norms in Indonesia is shown when the entrepreneur's norms persuade the government and the people of Indonesia. This stage is referred to as framing the agenda [10].

The success of norm entrepreneurs on framing the agenda was followed by the next stage called norm acceptance. The tipping point phase occurred in 1990-1991 proved by Indonesia's ratification of the CRC in September 1990. Since that, Indonesian government has made some adjustments in its legislative system in order to comply with the articles of the CRC, like the renewal of a number of laws.

From the periodic reports submitted to the UN Committee on the Rights of the Child, it can be seen that the progress achieved by Indonesia is quite rapid. This is a confirmation of the second stage characteristic in the theory of norm diffusion in Indonesia, namely the use of institutionalization and socialization mechanisms as the dominant mechanism of norm acceptance [11].

After going through the stage of norm acceptance, then Indonesia enter the stage of norm internalization. It can be seen that in Indonesia the norms of child protection and participation have been considered to be something taken for granted since 2015. This is evident from the institutionalization of the Children's Forum, the Children Friendly City (KLA) program, and the preparation of periodic reports to the UN Committee on the Rights of the Child.

In line with Finnemore and Sikkink's diffusion of norm theory, Acharya's localization theory emphasizes the importance of institutional and local structures as norms entrepreneur. In Indonesia. UNICEF and INGOs are norm entrepreneurs in internalizing the norms of child participation that collaborated with local non-government actors NGOs) in guarding the entry of new norms into the local bureaucratic system [10].

C. The Resistance among Indonesian Society

Acharya as cited by Zimmermann [9] mentions that in the theory of localization, there are three possible outcomes of globalization of norms that will arise, namely localization, resistance, and norm displacement. From the discussion above it can be concluded that the diffusion of norms of participation of children has gained support from the government, meaning that the acceptance of norms of child participation in Indonesia has reached the final stage in Finnemore and Sikkink's theory, namely norm internalization. The legislation process and bureaucracy have deliberately 'adjusted' and complied with the principles and spirit of CRC.

From this point, this study uses Acharya localization theory to analyze the resistance among Indonesia society on the diffusion of global norms of child participation. According to Acharya, the diffusion of the norms in internalization stage is in non-linear (straight) nature, but it moves in three possible alternatives: resistance, norm displacement, or localization [9]. There are some resistances in the Indonesian society as a result of the diffusion of norms of child participation. 
There are two types of resistance, namely cultural resistance and resistance based on religious interpretations. The cultural resistance occurs because of traditional beliefs such as children will be cursed should they do not obey their parents. Religious interpretation-based resistance rises in accordance to the Moslem majority in Indonesia that believe children should not have their own right until they are baligh (adult). In tackling religious-based resistance, the norm entrepreneur needs to involve religious leaders such as the Indonesian Ulama Council (MUI) in internalizing the norms.

\section{Conclusion}

The diffusion of norms of child participation in Indonesia is done by the norms entrepreneurs, such as UNICEF and INGOs working on child issues. Through the Finnemore and Sikkink's concept of diffusion of norms, it can be seen that in the Indonesian government, the norm of participation of children has reached the final stage; the internalization of the norms. This is proved by the existence many laws to fulfill and protect the rights of children and the institutionalization of networks to facilitate in children's participation.

In contrast, there is still several resistances in Indonesian society in internalizing the child participation norms. Resistance is categorized into two types, namely cultural and religious interpretation-based resistance. To overcome cultural resistance, journalists, culturalists, and artists need to be involved in building public opinion to be friendlier and accommodating to the rights of children. Meanwhile, to overcome the resistance that comes from the religious interpretation, the government and the norm entrepreneurs can collaborate with religious leaders such as the Indonesian Ulama Council (MUI) in the campaign to promote children's rights. Armed with a fatwa issued by the MUI, it is believed that the internalization of this norm will more successfully. However, the influence of the involvement of local actors and ulama in the internalization of children's participation norms, for sure, requires further research.

\section{References}

[1] G. Lansdown, Promoting Children's Participation in Democratic Decision-Making, Florence: UNICEF Innocenti Research Center, 2001.

[2] P. Cook et al, Children as Partners: Child Participation Promoting Social Change, Victoria: International Institute for Child Rights and Development, 2004.

[3] Dermawan et al , Guidelines for Developing a National Children's Forum, Jakarta: Assistant Deputy for Children's Participation, Deputy for Child Growth KPPPA.,2015.

[4] UNICEF Indonesia, Annual Report, Jakarta: UNICEF Indonesia, 2015.

[5] N. Thomas and B. Percy-Smith, A Handbook of Children and Young People's Participation: Perspective from Theory and Practice, New York: Routledge, 2010.

[6] A.E. Hara, Pengantar Analisis Politik Luar Negeri Dari Realisme sampai Konstruktivisme, Bandung: Penerbit Nuansa, 2011.

[7] J.J. Ring, The Diffusion of Norms in The International System, PhD's Dissertation Iowa: Iowa Research Online - University of Iowa, 2014.

[8] A. Acharya, 'How Ideas Spread: Whose Norms Matter? Norm Localization and Institutional 
Change in Asian Regionalism’, International Organization 58, 2004.

[9] L. Zimmermann, 'Same-same or Different? Norm Diffusion between Resistance, Compliance, and Localization in Post-Conflict States', International Studies Perspective 17, 2016, pp. 98-115

[10] M. Finnemore and K. Sikkink, 'International Norm Dynamics and Political Change'., International Organization 52, 1998.

[11] Committee on the Rights of the Child (CRC), Concluding Observation: Indonesia. Combined Third and Fourth Periodic Report, Geneva: United Nations Committee on the Rights of the Child, 2014. 